\title{
Un usage singulier des techniques : le travail des agricultrices dans les exploitations familiales
}

\section{Christian Nicourt}

\section{(2) OpenEdition}

12 Journals

Édition électronique

URL : https://journals.openedition.org/tc/429

DOI : $10.4000 /$ tc. 429

ISSN : 1952-420X

Éditeur

Éditions de l'EHESS

\section{Édition imprimée}

Date de publication : 1 octobre 1998

ISSN : 0248-6016

\section{Référence électronique}

Christian Nicourt, «Un usage singulier des techniques : le travail des agricultrices dans les exploitations familiales », Techniques \& Culture [En ligne], 30 | 1998, mis en ligne le 28 octobre 2005 consulté le 29 septembre 2022. URL : http://journals.openedition.org/tc/429 ; DOI : https://doi.org/ $10.4000 /$ tc. 429

Ce document a été généré automatiquement le 29 septembre 2022.

Tous droits réservés 
Un usage singulier des techniques : le travail des agricultrices dans les exploitations familiales

Christian Nicourt 